\title{
Discussion on Measures to Improve the Practical Skills of Students Majoring in Construction Engineering Technology in Higher Vocational Colleges
}

\author{
Yong Yin ${ }^{1,2, *}$ Hong Zeng ${ }^{1,2}$ Xiaolei Zheng ${ }^{1}$ \\ ${ }^{1}$ Chongqing JIANZHU College, Nan'an, Chongqing 400072, China \\ ${ }^{2}$ Prefabricated Construction Applied Technology Promotion Center of Chongqing Higher Vocational College, \\ Chongqing 400072, China \\ *Corresponding author. Email: 103237256@qq.com
}

\begin{abstract} adapt to the needs of enterprise and the society.

\section{INTRODUCTION}

Construction engineering technology is a major with strong practicality. This specialty cultivates welldeveloped and skilful talents possessing solid theoretical and professional knowledge. After taking this specialty, students are expected to be high-quality technical and skilled professionals with good professional ethics and spirit, and become competent for the positions of construction, supervision, cost, quality safety and technical data management, and obtain the ability of innovation and sustainable development.
\end{abstract}

According to the author's years of teaching experience in higher vocational construction engineering specialty and engineering site management experience, combined with the current demand of construction engineering talents, this paper put forward some measures from many aspects to improve the practical ability and skills of students majoring in construction engineering technology in higher vocational colleges, including the construction of teaching staff, the development of practical courses, the improvement of practical training conditions, the in-depth of school-enterprise cooperation, the promotion of teaching and learning by competition. Through the above measures, it aims to improve students' professional quality, cooperation quality, innovation and moral quality. In addition, it targeted at training students' learning ability, communication and cooperation ability, sense of responsibility, problem-solving ability, innovative thinking ability, argumentation ability and self-discipline ability, so as to obtain the practical skills better and faster to

Keywords: Construction engineering technology, “double-qualified” teachers, skill, training, practice

\section{BACKGROUND AND CURRENT STATUS}

The practical skills of students majoring in construction engineering technology in higher vocational colleges are an important quality throughout their career. According to the Implementation Plan of the National Vocational Education Reform in 2019, vocational education and general education are two different types of education with equal importance. Since the reform and opening up, vocational education has provided strong talent and intellectual support for China's economic and social development. The framework of modern vocational education system has been built in an all-round way, and its ability to serve economic and social development and social attraction have been continuously enhanced. It has many favourable conditions and good working foundation for basically realizing modernization. With China entering a new stage of development marked by accelerating industrial upgrading and economic restructuring, there is more urgent demand for technical and skilled personnel in all walks of life. The important position and role of vocational education are becoming more and more prominent. However, compared with the developed countries and the requirements for building a modern economic system and a powerful country in education, there are still some issues existing in China's vocational education. Specifically, the system construction is not sound; the construction of vocational skills training base needs to be strengthened; the system standards are not perfect; the motivation of enterprises to participate in the development of colleges is insufficient; the supporting policies conducive to the growth of technical talents need to be improved; the quality of education and personnel training is uneven. There is an urgent need to make great efforts to solve the problems.

At present, China's vocational education does not meet the needs of social development. Students trained by vocational education are lack of practical ability and innovation ability. Under the background of traditional training mode, students receive relatively complete knowledge education, but the cultivation of students' 
practical ability is ignored. Students trained in this way are often rich in theoretical knowledge and weak in practical ability.

This requires the school to improve the setting of practical courses in the teaching system[2]. The construction of practical courses with professional characteristics requires the participation and design of industry experts. The school and the enterprise work together to determine the content of practice. The purpose of practice course is to improve students' professional level, and enable students to fully understand the importance of professional skills and their contribution to the development of enterprises in the process of practice, so as to strengthen students' sense of responsibility and teamwork spirit. On the premise of the business philosophy and development strategy of construction industry enterprises, we should promote the reform of school practice curriculum; constantly improve the development of the practice teaching system.

\section{PRACTICAL SKILLS IMPROVEMENT MEASURES}

The practical ability of students in higher vocational colleges cannot fully meet the needs of enterprises; the skilled teachers are lack; practical training is disconnected from the actual needs of enterprises. These problems require us to find good measures to improve practical skills. Combining with the author's years of teaching experience of construction engineering specialty in higher vocational colleges and site management experience, as well as the in-depth understanding of market demand for talents of construction engineering specialty, five constructive strategies are put forward for the cultivation of practical ability of students majoring in construction engineering technology in higher vocational colleges.

\subsection{Strengthen the construction of "double- qualified" teaching staff}

The construction of "double-qualified" teachers is the theme of the construction of vocational teaching staff in China at the present stage. [3] Strengthening the training of vocational teachers with the characteristics of "double qualification" teachers is an important way to improve the overall quality of vocational teachers, optimize the structure of teaching staff, and address the shortage and low quality of professional teachers and practice instructors in vocational colleges. According to the evaluation method of the Ministry of education, the proportion of "double quality" teachers in foundation courses and specialized courses must reach $70 \%$ before they are qualified. Today the proportion of high-quality teachers with double qualifications in higher vocational colleges is far from the regulations of the Ministry of education.

Due to the booming real estate market in the early stage, the salary of project management is relatively high, while the salary of teachers in higher vocational colleges is generally low, which makes it difficult to attract project managers with rich practical experience. Nowadays, most of the teachers in higher vocational colleges are fresh graduates, and there is a lack of backbone teachers and professional teaching leaders with front-line work experience and rich practical experience. [4] Due to heavy work tasks, on-the-job teachers have few practical opportunities such as temporary training and internship in enterprises. Owning to the weak practical ability of most teachers, the ability-based principle of higher vocational education is difficult to be effectively implemented. The current situation of teaching staff restricts the characteristic development of higher vocational colleges and seriously affects the higher vocational colleges to provide the society with advanced applied technical talents. In this paper, some suggestions are put forward to strengthen the construction of "double qualification" teaching staff.

\subsubsection{Enhance the assessment of work experience in the recruitment of teachers in higher vocational colleges}

According to the requirements, professional teachers in colleges and universities should have at least two years' practical work experience in the discipline they are applying for or complete a project management work systematically. Priority should be given to the introduction of personnel with rich working experience, strong expression ability and "double qualification". We should fully assess the teachers in the interview process to eliminate personnel without any practical experience to engage in professional course teaching.

\subsubsection{Appropriately lower the academic requirements of professional course teachers}

Today, the recruitment of teachers in higher vocational colleges mostly aims at doctoral degree or above, which leads to a large number of undergraduate and graduate students with rich work experience missing out on the opportunity to work in higher vocational colleges. However, the salary standard and scientific research funds of higher vocational colleges are not enough to arouse the interest of doctoral students, so that those who want to work cannot come, and those who don't want to come can't be attracted. It is suggested to recruit training instructors with bachelor degree or above and professional course teachers with graduate degree or above. If teachers have strong professional skills, the education requirements may be relaxed to bachelor degree. 


\subsubsection{Strengthen the training of teachers to improve their professional level and increase the proportion of "double quality" teachers}

For historical reasons, some teachers without "double quality" have engaged in professional course teaching, resulting in students' dissatisfaction. It is an important task for higher vocational colleges to strengthen the professional training of these teachers. We can increase rewards to improve their internal driving force for selfimprovement. The opportunities of school-enterprise cooperation, internship and professional training should be inclined to them as far as possible and tutorial system should be adopted to promote their growth.

The norms of the construction industry are constantly being updated. New materials, techniques, technologies and methods are emerging. Many long-term project management staff are also difficult to keep up with the pace of the times. Teachers in higher vocational colleges should keep up with and even go ahead of the times to consolidate their own "double-quality". I think it is a good choice for teachers to work part-time in enterprises, engaging in project management. Teachers in our college are mainly engaged in technical consulting, design, supervision and other work, which not only creates value for society, but also improves their professional level. These teachers have strong professional quality that their teaching quality has been unanimously recognized by students, school leaders and teachers. They play a positive role in promoting students' professional skills. With the roll out of "national social security", teachers at college and university are included in the scope of social security. At the same time, the state has strengthened the qualification access of project management personnel. Social security has become an obstacle for teachers in higher vocational colleges to work as project management personnel. It will also become a stumbling block for teachers in higher vocational colleges to use their spare time to contribute to society and improve their teaching ability. Now the policy is fully implemented, it's believed that both advantages and disadvantages will be fully revealed.

\subsection{Stick to the curriculum system and standards, carry out practical teaching and improve training conditions}

Professional skills cultivating is an important part of the curriculum in higher vocational colleges[5]. When setting the curriculum, we should first consider whether the students are suitable for the market and the industry, and then think about implementation feasibility and professional matching. We should set up a reasonable curriculum system of higher vocational education based on the practical ability of the position and the occupation demand.

The curriculum system and standards of higher vocational colleges have been strictly discussed by teachers and demonstrated by experts. Generally speaking, its standard and system are generally reasonable and meet market demand. If we respect the curriculum system and standards and put the practical curriculum teaching into practice, it will greatly promote the improvement of students' professional skills.

\subsubsection{There are still some constraints in the development of professional practice, mainly in the following points}

\subsubsection{Lack of training teachers}

[6]Today many higher vocational colleges have established large-scale training bases and purchased training equipment, but the training work has not been carried out yet, which is directly related to the lack of training teachers. Teachers in higher vocational colleges generally have master degree or above and are unwilling to be practical instructors. Yet schools are reluctant to lower academic requirements to recruit skilled workers to fill mentoring positions. But there are differences between professional course teachers and practical teachers, one is pure theory teaching, the other is the integration of theory and practice. There are many corresponding training projects in construction engineering technology, such as steel fixer training, template worker training, scaffolder training, bricklayer training, plasterer training, etc. The contents of these jobs are taught in a course of construction technology. It is really a difficult thing for a construction technology teacher to master the practical training operation of all kinds of jobs.

\subsubsection{Lack of training materials}

Many colleges carry out practical training without practical training materials, but mainly use curriculum materials to carry out practical training based on their own experience. There are many practical training standards in the same practice project, which leads to poor practical training effects and many risk factors in the process. Lacking practical experience, some young teachers teach in full accordance with book knowledge, which makes it difficult for students to apply what they have learned to the practice on the site.

\subsubsection{The procedure for teachers to carry out practical training is complicated}

A practical training course requires the teacher to do a series of work, including preliminary application of course and material, classroom teaching, safety management, after-class practical training report and so on. Compared with ordinary in-class teaching, the workload of teachers has increased by about 2-3 times. Instead of increasing 
teachers' compensation, the risk of safety management increases. As a result, many teachers are unwilling to carry out practical training.

\subsubsection{Eliminate constraints and carry out practical teaching}

The above factors that restrict the implement of practical training courses should be comprehensively considered from the aspects of the allocation of practical training instructors, the compilation of practical training textbooks, and the simplification of practical training procedures, so as to realize the normal development of practical training. (1) It is necessary to establish school-enterprise joint education, build a multi-faceted training education perspective, and introduce technicians and skilled workers from enterprises to schools to solve the problem of shortage of practical training teachers. Through a series of measures, such as making policies for the introduction of skilled talents, strengthening the training of young teachers, and building a platform for the growth of young teachers, young teachers will become versatile, integrating theory with practice and gradually become the backbone of practical education.

(2) It is suggested that loose-leaf teaching materials for practical training should be developed according to the characteristics of action-oriented courses in higher vocational colleges, combining the structure of new looseleaf teaching materials and the core idea of competenceoriented.

(3) Two levels of practical training management should be established. The experimental and training center of the college is responsible for the planning and construction, system construction and safety management of the experimental and training base of the school, as well as the management and operation of the public experimental and training platform. The training room of the department is responsible for the construction of experimental training conditions and performance evaluation of management of the department, which can effectively reduce the training procedures.

\subsection{Carry out in-depth school-enterprise cooperation, master the direction of practical skills, and improve the level of practical skills}

The content and level of practical skills to be learned in higher vocational colleges are most directly related to the needs of enterprises[7]. We should carry out schoolenterprise cooperation and communication; timely understand the needs of enterprises to train qualified skilled personnel for enterprises. The construction site and workshop of the enterprise can also serve as the practice base for students.

However, school-enterprise cooperation in many schools is only superficial without carrying out substantial work. Therefore, in-depth school-enterprise cooperation is very important. Enterprises should participate in the preparation of school curriculum standards and training materials. We should invite as many experienced managers as possible to participate in school teaching.

\subsection{Participate in the vocational skills competition}

The skills competition shows the teaching achievements of colleges and universities, expands the social influence, stimulates the growth of teachers and students, and guides a good style of study and so on[8]. It can also provide the basis for the revision of the talent training plan. By adjusting the curriculum setting and optimizing the curriculum structure, we can promote the close combination of professional courses and skills competition, promote the innovation and implementation of productive practice, further highlight the practical teaching system of post-education, and form a good atmosphere of promoting teaching, learning and training by competition.

\subsection{Strengthen students' awareness of planning practice ability, improve students' sense of urgency of employment under the pressure of real estate inventory}

Under the pressure of destocking, real estate developers postpone or cut some projects, resulting in a sharp drop in the demand for construction engineering students in the real estate market. At present, the number of construction engineering graduates has not decreased. Facing the situation that the huge cake suddenly becomes smaller, how to get a share in the fierce market competition will be an important problem that vocational college students have to face.

The target of practical ability cultivation is students who are the subject of acquiring practical skills. No matter how external factors are cultivated and shaped, they should play a role through students' internal factors. Therefore, when higher vocational colleges improve students' practical ability, they should first mobilize students' internal cause, namely students' internal development, which comes from their own needs. The second is to strengthen students' career planning awareness, so that students stimulate selfimprovement awareness, change the passive acceptance of learning habits, and actively participate in learning.

\section{CONCLUSION}

Through the construction of "double-qualified" teaching staff, we can improve the teaching level of practical teachers, establish the sense of responsibility and superiority of practical education, and take root in practical teaching, so as to better serve the development of practical training in schools and improve students' practical skills. 
We should earnestly carry out the practical course teaching, constantly improve the practical training conditions, and strive to strengthen the school-enterprise cooperation so as to implement the practical training work. With good teaching materials, teachers no longer have to worry about training. With the high-quality training base, students' training content can be fully in line with the needs of enterprises. Skill competition provides a guiding benchmark for practical teaching reform. Combining with the vocational demands, practical teaching takes professional ability as the standard, and converts the work content and process in the real work field into the core task of teaching. It should organize the teaching content according to the work task, optimize the teaching process and promote the work of practical teaching.

The improvement of practical skills of students majoring in construction engineering technology in higher vocational colleges is a complex process, which is affected by many factors such as teaching staff, source of students, the demand of enterprises, and the stage of social development. With a sense of serving society and for the benefit of our students, we should always think about ways to improve our skills and apply them to practice. After the measures put forward in this paper are applied to practice, students' practical skills are greatly improved.

\section{REFERENCES}

[1] Chen Shibang. A Study on the Joint Education Practice of Vocational Skills and Professionalism Under the Modern Apprenticeship System-Taking the Higher Vocational Foreign Trade Major as an Example [J]. China Market, 2020(32):181-183.
[2] Liu Hongxiang. Research on Academic Assessment of College Students Promoting Creativity Cultivation [D]. Hunan Normal University, 2019.

[3] Fu Hanfei. Research on the Construction of "DualQuality" Teacher Team in Higher Vocational Institutions under the Background of Integration of Industry and Education [D]. Hubei University of Technology, 2020.

[4] Wang Meng. The Research on the Construction of "Double Type" Teachers Team in Independent Colleges [D]. Soochow University, 2019.

[5] Li Zheng. A Study on the Value of Modern Apprenticeship in Vocational Education [D]. East China Normal University, 2019.

[6] Zhou Weihong. A Research on the Co-construction and Sharing of Vocational Education Training Bases in Shanghai[D]. East China Normal University, 2017.

[7] Wang Yanan. Research on the Construction and Development of Competency Model for Professional Leaders in Higher Education Institutions [D]. East China Normal University, 2018.

[8] Chen Xiaoqiang. Practical Exploration of Effective Integration of Vocational Skills Competition and Professional Teaching [J]. Daylight Science for Kids (Education Research), 2020(12):7. 